\title{
Music in Prehistoric Armenia
}

\author{
Ani Petrosyan, Arsen Bobokhyan \\ Institute of Archaeology and Ethnography, National Academy of Sciences, Yerevan, Republic of Armenia
}

\begin{abstract}
Within the syncretic world view of prehistoric people, there was an inseparable link between word, song, and dance. Hence it is not easy for the modern researcher to outline the border between these spheres. Using interdisciplinary methods, present paper touches the case of Armenian monodic music. Through analysis of song types (concerning labour, funeral, wedding, belief, worship, magic, mythology, epic, and dance), music representatives, music performance places, and musical instruments, an attempt is made to consider the phenomenon within certain temporal borders. It turns out that the folk and folk-professional realistic music is simple and static in its essence and includes the invariant component of local culture, going back to the period of formation of early farming communities. Meanwhile with emerging social complexity since the Bronze Age, new and various forms of musical performance come to existence.
\end{abstract}

Keywords: early music, ethno-historical approach, Armenia

\section{Introduction}

During the last century, great work has been done in the study of Armenian Christian and pre-Christian music by such musicologists and folklorist-ethnographers as Komitas, Abeghyan, Kushnaryan, Tahmizyan, et al. (cf. Abeghyan, 1899; Melikyan, 1935; Komitas, 1941, Abeghyan, 1946; Kushnarev, 1958; Aghayan, 1959; Kushnaryan et al., 1963; Barsamyan \& Harutiunyan, 1968; Tahmizyan, 1975; Tahmizyan, 1982). Prehistoric forms of Armenian music were discussed more in ethnographical and less in historical and archaeological context. Notes about music in ancient Armenia were limited as a rule to description and comparison of particular musical instruments (cf. Khanzadyan, 1959; Kushnareva, 2000; Khachatryan, 2001; Seidl, 2009). The main objective of this study is to partially fill in the mentioned gap.

One of the problems concerning investigation of early forms of music is that the music as a universal phenomenon interacted within various spheres of social life. Besides, in ancient societies there was an inseparable link between word, song, and dance during every day life (for syncretism of thought cf. Abramian 1983), and in case of reconstruction of ancient music, these spheres are often intercrossed and it is not easy to outline the border between them. Another problem is that, as a rule, the traces of early music have been preserved within beliefs, habits, and poems to be recorded during medieval and new times. Hence, we should be cautious, as most of them were introduced with a new content while preserving their early forms.

Our methodology to approach the problem is interdisciplinary: Ethnographical and folkloristic data are discussed together with historical and archaeological evidence. Only their juxtaposition gives an opportunity to interpret the problem more precisely. Besides, it is important to trace the musical developments in the context

Ani Petrosyan, master, Institute of Archaeology and Ethnography, Armenian Academy of Sciences.

Arsen Bobokhyan, doctor, Institute of Archaeology and Ethnography, Armenian Academy of Sciences. 
of general historical processes. For example, it is logical to assume that in the result of development of economy, in particular, agriculture and animal-husbandry, the number of songs linked to labour increases. Based on this it becomes possible to suggest a possible terminus post quem for archaic songs.

The history of Armenian music can be conditionally divided into three main phases: prehistoric (from earlier periods of formation of farming communities until the establishment of Urartian kingdom using cuneiform script at the end of the 2nd millennium B.C.), early historical (the Urartian, Antique and Hellenistic periods, ca. 1000 B.C.-300 A.D.), and late historical (since early medieval times). Our research refers only to the first, prehistoric stage. The other periods are mentioned for diachronic comparisons.

\section{Ethno-historical Perspective}

The basics of the system of expression of Armenian "musical language" are laid within "Armenian" spoken language in prehistoric period, when initial melodic figures, musical genres, and forms were formulated. A question arises: In which sphere of folk study, the remains of archaic modes, genres, and forms must be looked for? Certainly in the music that is linked to agricultural and pastoral activities. The comparative study of labor songs (horovel, gutanerg), which were preserved among the Armenians until recent times, reveals that there are several exclamation-phrases in the same modal system. These are initial and main core of compositions of that genre. The exclamative motives were addressed to the cattle or underground powers to which the cultivator addressed for the work success. The archaic forms of horovels and funerary songs are examples of how the musical intonations originate in the depth of speech intonations (Komitas, 1941; Kushnaryan et al., 1963).

As in case of other nations of ancient world, the everyday-domestic music existed in the period of formation of kinship relations. That kind of music was inseparably connected to rituals emphasizing the most important moments of life of a patriarchal family members. Armenian wedding, funerary, and other ritual-everyday songs bring the evidences of that antiquity (Kushnarev, 1958).

The research reveals that traditional forms of music stood extremely stable, while they passed through generations, and are reflected in myths. For example, until recent times the songs about Mesopotamian queen Shamiram (Semiramis) were performed by the folk. Also the epic tale "Sasna Tsrer" (Daredevils of Sasun) contains such ancient layers and musical reflections. The same can be noted for wedding and funerary rituals. Regardless of the fact that these motifs are found in different regions of Armenia, they always have the same formal features (Kushnaryan et al., 1963, pp. 11-12).

\section{Song Types}

Epical-historical, lyrical, ritual, and labour songs represent the most sustainable genres of ancient Armenian music being reconstructed on the bases of medieval and new recordings (for typology cf. Komitas 1941, pp. 9-14). In the works of medieval Armenian historians, especially in the narrative of Movses Khorenatsi (fifth century A.D.), the names of ancient song types have been preserved. Among them are "erg banitsn" (story-telling songs), "paruts" and "tstsots" (small lyrical songs), "tveleats" (narrative songs), which were sung by vipasans (epic-tellers). The song types called "qnarakan qerdutyun" included blessing (sacred), heroic, moral-philosophic and entertainment songs (Abeghyan, 1899, p. 34; cf. Barsamyan \& Harutiunyan, 1968, p. 15). The epic "Daredevils of Sasun" also belongs to the abovementioned narrative genre. Myths, folk traditions, and real historical happenings of prehistoric past were included in it. Unfortunately, its musical 
component has hardly survived until modern times. However, the known musical fragments of the epos prove that tellers used various forms of expression: talk, declamation, melodic recitative and, finally, song. Such songs from the epos as "Msra Melik" and "Zoghormi” are the motives, which contain the most archaic layers (Melikyan, 1935, p. 57).

As it was mentioned above, the labour songs connected with agriculture and animal husbandry were the most archaic type. Farmer's everyday struggle for survival is reflected in invocative-magical songs and recitatives. These were aimed to repel evil spirits. "The Song of Grindstone” could be mentioned among ancient labour songs. It was performed while the cereal grains were pounded. Among them the songs on sowing (“Hep-hop”), spinning-wheel (“Teli Manogh Nargiz”), and milking (“Ilili-dilili”) are worth to mention (Kushnarev, 1958, pp. 52-55; Barsamyan \& Harutiunyan, 1968, p. 4). Some fragments of ritual songs linked to agricultural cycle survived until our days. For example, spring feast jangyulums or vardavar songs devoted to the goddess of love and fertility Astghik. Most of the youth songs known as yayli, gyovnd, or simple dance songs are attributed to the same type of art works. These are particularly preserved in the folk materials of ethnographic region Sasun. The elements of lyrics arise from such kind of songs. A variant of "Habrban" is an example of youth song that has archaic features (Kushnaryan et al., 1963, p. 18). In this context, rain invoking rituals should be mentioned during which the songs were performed with accompaniment of musical instruments, especially of a drum. That kind of ritual called "Chichi-Mama” was preserved in ethnographic region Bardzr Hayk (Erzurum): Ten to twenty adult women participated in a ritual procession through the settlement, one of them held a cross in her hand, the other one—a drum, asking for fertility (Bdoyan, 1968, p. 117).

Archaic melodic traits are evident also in examples of pastoral music. These were performed in Armenia by herdsmen on longitudinal flute (Kushnaryan et al., 1963, p. 15).

The songs of funeral rite have been hardly transformed during the time. Ritual weeping that originated from spoken sayings was called "sug" (sorrow) and "voghb" (weeping). Here the musical intonation is combined by speaking. In general, the constitution of these and agricultural songs is defined as improvisational recitative. In that case, the older, pre-Christian funeral ceremonies described by medieval authors certainly have prehistoric substratum. The remains of pagan funeral rituals described by those authors could be traced in towns and villages of Armenia until recent times (Kushnaryan et al., 1963, p. 18; Barsamyan \& Harutiunyan, 1968, p. 6).

The issue of wedding songs is quite different. These songs, like funeral ones, originate in early period of formation of patriarchal kinship system, but changed more during the time. The primary content of the wedding songs, their role, significance in everyday life as well as their forms transformed along with changing requirements of wedding life. Nevertheless, there are examples of preserved wedding songs with archaic traits from compositional viewpoint. That is particularly evident in the folklore materials from ethnographic region Sasun. Here, examples of songs towards farewell weeping of the bride and ceremonial praise leave an impression of extreme antiquity (Kushnarev, 1958, pp. 33-34; Kushnaryan et al., 1963, p. 19). A custom from ethnographic region Vaspurakan is noteworthy, according to which the newly-wed addressed the sun during the sunrise with a song to gain long life, in which Vahe, a pre-Christian Armenian god, is the central figure (Barsamyan \& Harutiunyan, 1968, p. 5).

The songs related to beliefs, animistic worships and magic are also archaic (cf. e.g. "Hoynar", "Naroy" songs) (Barsamyan \& Harutiunyan, 1968). The elements preserved in Armenian manuscripts called "Hmail" 
and "Urbatagirk" (both with meaning "Talisman books") give an idea about initial songs linked to various rituals and ancient beliefs. These elements are transformed samples of magical formulas that consisted of short and repeating words (Tahmizyan, 1982, p. 6). Magic monodies are also of an ancient origin. These were spread not only among priests, but also among ordinary members of patriarchal society. Unfortunately, there are no records of original magical melodies, meanwhile the influences of their rhythms and inflexions are reflected in manuscripts and ethnographic texts (Abeghyan, 1946, pp. 17-18).

Songs illustrating the birth of the god Vahagn or fights of the hero Tork Angegh belong to ancient mythological songs. Numerous folk theatrical celebrations with musical accompaniment are devoted to dying and resurrecting god Ara who embodies the spring awakening, the cycles of agricultural works. Among these songs, it should be mentioned "Tsamtelik" and "Deriko hoynar": The first one refers to the queen Semiramis (her magical beads), and the second one to mother Semiramis, a mythical goddess Derketo (Kushnarev, 1958, pp. 70-71; Barsamyan \& Harutiunyan, 1968, pp. 70-71).

The epic songs are also prehistoric by their nature, which tell about the struggle against foreign countries, such as Mesopotamia. The ancient period of history of Armenia and formation of Armenian nation is reflected in them. In particular, the songs about combat between Hayk, the eponym of the Armenians and Bel, his enemy, were famous. A complete cycle of epic songs is devoted to the patriarchs Aram and Ara Geghetsik (the Handsome) who fight for independence of their country (Barsamyan \& Harutiunyan, 1968, p. 6).

There are archaic samples also among dance motifs. A perfect example of that type is one of the numerous variants of pastoral dance "Kochari", which is known also by the name "Akh, le, le". That is a small and often repeated motif, which consisted of one strophe. It is noteworthy that the mode here is the same as in ancient horovels and sorrows. This is a case when the analysis of compositional features of the song reveals to which historical layer the origin of the song type should be attributed (Lisitsyan, 1958).

Discussion of musical works of archaic content reveals that the structure of Armenian folk music was initially monodic. However, if the sorrows, magical motifs, and probably horovels were performed by soloists, then the dance melodies were realized in group by all participants of the action.

\section{Music Representatives}

The main bearers of musical culture in ancient Armenia were gusans (male) and vardsaks (female) functioning as multiple-discipline actors—singers, players, dancers, poets, story-tellers, spontaneous improvisators during disputes. They played the same role as mimes (jesters) in ancient Greece or jugglers in medieval France (Aghayan, 1959). Gusans were divided into groups: One part served to the elite, the other to wider public. They differed from each other by specialization. Some of them (called vipasans - epic tellers) told legends and novels, the others participated in ritual ceremonies (wedding, funeral) or entertained the guests during feasts, parties, and "big celebrations". In the second group of gusans there were singers, players, dancers (kaqavichq), and jesters. The third group of the gusans was devoted to the theatre as mimes, comical actors (katakagusan) as well as tragedy actors (dzainarku gusan) (Kushnaryan et al., 1963, pp. 19-33).

Gusan-vipasans did a great work in passing the epic works. That is evident in the case of "Daredevills of Sasun". It was told by gusan-vipasans with accompaniment of different musical instruments (especially pandir, a string instrument) declaring and sometimes singing the poem fragments (Tahmizyan, 1989, pp. 12-13). The people loved and appreciated the art of gusans. Gusan talks and songs are called "the spiritual food of the peasants” by historian of the fifth century A.D. Pavstos Buzand (Abeghyan, 1946, p. 64). These songs 
reflected also real information and Armenian historians gained precious data from them on history of ancient Armenia.

\section{Music Performance Places}

The musical art of folk masses to be linked to labour activities and cult (rituals of agricultural cycle and feasts) was performed mainly in natural environment. The ceremonies of ruling elite had limited nature and were held in temples by priests or in palaces by gusans (Kushnaryan et al., 1963, p. 20). Thus, gusans acted during the public holydays in the squares, in front of the temples and in palaces, performing religious and entertaining songs and dances. The ancient magical-ritual actions that have syncretic nature formed the basis for two independent branches of gusan art. The first one played an important role in development of professional theatre, the other one in development of musical art. The study of theatre history shows that singing and music were the most important features of theatre action. During the first phase of development of theatre in ancient Armenia the gusan theatre was formed. It was closely connected to worship, ceremony, particularly, concerning dying and resurrecting deities. Among these are the legends about Ara the Handsome, Murane goddess, and her son Gisane. There were various genres in the theatre of pre-Christian Armenia: Gusans and vardzaks presented the theatre of mimes, comedians and comedian-gusans - the theatre of comedy, tragedians and weeper gusans - the theatre of tragedy (Goyan, 1952, p. 433; cf. Petrosyan, 2006). Thus, the performances of gusans represent the prehistory of Armenian professional theatre.

\section{Musical Instruments}

Towards ancient Armenian musical instruments we can judge by ethnographical, historical, and archaeological data. Therefore, in the epic "Daredevils of Sasun" besides gusans also instruments (tambur/tamburine, saz/a kind of lute) are mentioned (cf. Barsamyan \& Harutiunyan, 1968, pp. 21-24). According to medieval historians, stringed (harp, lyre, lute), wind (horn, pipe, trumpet), and percussion (drum, tambourine) instruments were popular in ancient Armenia (Khanzadyan, 1959). Among them the longitudinal flute, on which pastoral melodies were played, goes back with its roots to archaic times and other instruments such as the lute (vin, jnar, which reminds later saz) goes back perhaps to Bronze Age: These instruments were played in Armenian villages until recent times (Khudabashyan, 2004).

Each of these instruments was used by the certain contingent of population as well as in certain spheres of everyday life. Thus, longitudinal flute was popular by working people; horns were played during palace feasts and wars. Armenians used also instruments for worship purposes: Among them can be mentioned ripidion (qshots), which was a percussion instrument similar to Egyptian sistrum and was realized for repelling evil spirits from temples (Kushnarev, 1958, p. 76).

The mentioned data are confirmed by archaeological evidence on musical instruments (cf. Kushnareva, 2000; Khachatryan, 2001), according to which during Bronze and Iron Ages (ca. 3rd-2nd millennia B.C.) the following stringed, wind and percussive instruments were known in Armenia: lyre, harp, lute, pipe-flute, drum, and bell-shaped objects. Also images of the parade with musical instruments are known from Armenia (cf. Bobokhyan, 2008, pp. 532-533) with parallels in Mesopotamia and Anatolia (see Figure. 1). Instruments such as the lute and bells could be originally typical for Armenia. The appearance of the harp/lyre must be connected to Near Eastern influences. Meanwhile, instruments like drums and pipes were characteristic of many societies and their similarities should be considered as a result of convergent developments. 

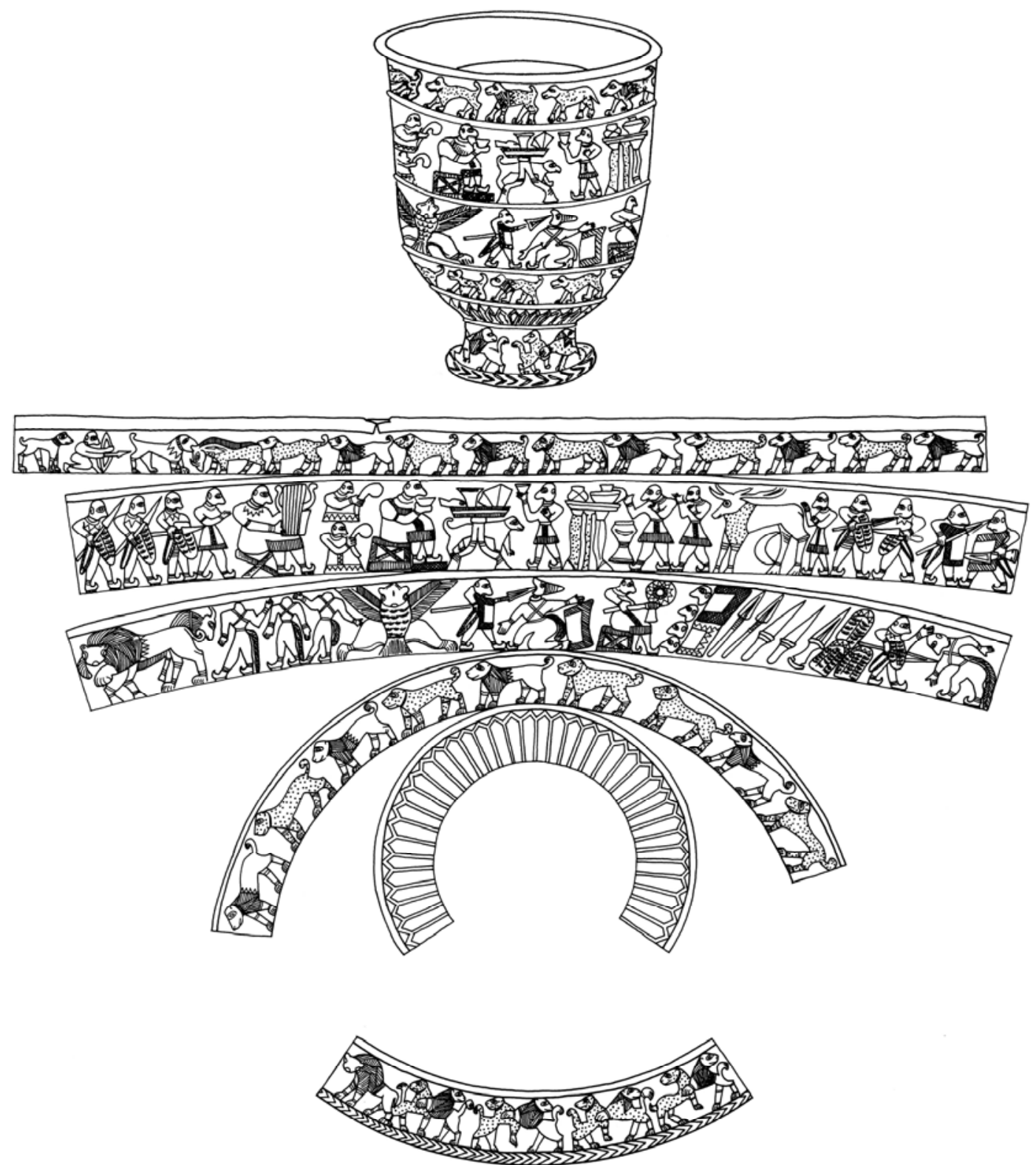

Figure 1. Silver goblet from Karashamb, barrow 1, Armenia, 22nd-21st centuries B.C. Iconography of ritual fight, procession and feast with involvement of musicians playing lyre and idiophones (second frieze).

\section{Conclusion}

Music was an important component in early societies to be linked to various spheres of social life. In the frames of syncretic way of thinking of prehistoric men, there was an inseparable connection between music, dance, and word art. The same is to note for Armenian reality.

By dating early music it is not possible to speak in absolute terms. We can try only to define the terminus post quem for beginnings of certain musical phenomena. For example, songs concerning labour, funeral rite, wedding, belief, worship, magic, mythology, many of dance motifs certainly go back to early farming societies (Neolithic and Chalcolithic periods). They are simple, connected to rural life and were performed mainly in natural environment, using longitudinal flute, perhaps also drum. Meanwhile, the epic songs, in which 
historical events are reflected, such as struggle against foreign countries (e.g. Mesopotamia, embodied in figures of Bel or Semiramis) by heroes Hayk, Aram, and Ara could have the Bronze Age as terminus post quem, although some of their traits could fit also to earlier periods. The formation of social complexity and elite culture in Armenia especially since the Middle Bronze Age (ca. 2000 B.C.) needed ceremonies held by special musicians (perhaps gusans) with various musical instruments (lyre, harp, lute, etc.) in temples, palaces or "theatres". However, many of the mentioned songs, and first of all the "Daredevils of Sasun", should be considered in diachronic perspective—-with many layers, to be excavated by archaeologists of music.

\section{References}

Abeghyan, M. (1899). Haykakan zhoghovrdakan araspelnery (Armenian folk myths). Vagharshapat: Mayr Ator.

Abeghyan, M. (1946). Hay hin grakanutyan patmutyun (History of ancient Armenian literature). Yerevan: Academy of Sciences Press.

Abramian, L. (1983). Pervobytnyi prazdnik i mifologiya (Archaic festival and mythology). Yerevan: Academy of Sciences Press.

Aghayan, M. (1959). Hay gusannnery ev gusanakan-ashughakan arvesty (Armenian gusan and gusan-ashugh art). Yerevan: Academy of Sciences Press.

Barsamyan, A., \& Harutiunyan, M. (1968). Hay erazhshtutyan patmutyun (History of Armenian music). Yerevan: Luys.

Bdoyan, V. (1968). Zemledelie v Armenii (Agriculture in Armenia). Tbilisi: University Press.

Bobokhyan, A. (2008). Kommunikation und Austausch im Hochland zwischen Kaukasus und Taurus, ca. 2500-1500 v. Chr. (Communication and exchange in the highland between the Caucasus and the Taurus, ca. 2500-1500 B.C.). Oxford: Hedges.

Goyan, G. (1952). Teatr drevney Armenii (Theatre of ancient Armenia). Moscow: Iskusstvo.

Khachatryan, Z. (2001). Representations of music on Armenian terracotas and toreutics (Second millennium B.C.-third century A.D.). Imago Musicae, XVIII/XIX(2), 85-98.

Khanzadyan, E. (1959). Haykakan hin erazhshtakan gortsikner (Ancient Armenian musical instruments). In Works of state historical museum of Armenia 5 (pp. 62-93). Yerevan: State Museum of Armenia.

Khudabashyan, K. (2004). Hay-pryugiakan ev hay-khetakan kapery erazhshtakan tesankyunits (Armenian-Phrygian and Armenian-Hittite musical relations). In V. Barkhudaryan (Ed.), Hayagitutian ardi vichaky ev zargatsman herankarnery (Present state of Armenian Studies and perspectives of development) (pp.447-452). Yerevan: Academy of Sciences Press.

Komitas, V. (1941). Hodvatsner ev usumnasirutyunner (Articles and investigations). Yerevan: Pethrat.

Kushnarev, K. (1958). Voprosy istorii i teorii armyanskoy monodicheskoy muzyki (Questions of history and theory of Armenian monodic music). Leningrad: Gosmuzizdatel’stvo.

Kushnareva, K. (2000). Some Evidence of Musical Instruments in Bronze Age Caucasus. In Studies in Music Archaeology II (pp. 103-112). Rahden/Westfalien: Marie Leidorf Press.

Kushnaryan, K., Muradyan M., \& Gyodakyan G. (1963). Aknark hay erazhshtutyan patmutyan (Sketches of history of Armenian music). Yerevan: Academy of Sciences Press.

Lisitsyan, S. (1958). Starinnye plyaski i teatral'nye predstavleniya armyanskogo naroda (Ancient dances and theatrical performances of the Armenian people). Yerevan: Academy of Sciences Press.

Melikyan, S. (1935). Urvagits hay erazhshtutyan patmutyan (Scetches of history of Armenian music). Yerevan: Luszhoghkomat.

Petrosyan, A. (2006). Haykakan avandakan dramayi akunkneri shurj (Towards the problem of the sources of the Armenian traditional drama). Historical-Philological Journal, 2, 256-284.

Seidl, U. (2009). Musik und Tanz in Urartu. In H.Saglamtimur (Ed.), Studies in honour of Altan Çilingiroğlu. A life dedicated to Urartu on the shores of the Upper sea (pp.607-617). Istanbul: Arkeoloji ve Sanat.

Tahmizyan, N. (1975). Knnakan tesutyun hayots hin ev mijnadaryan erazhshtutyan (Critical theory of ancient and medieval Armenian music). Herald of Social Sciences, 9, 27-40.

Tahmizyan, N. (1982). Erazhshtutyuny hin ev mijnadaryan Hayastanum (Music in ancient and medieval Armenia). Yerevan: Matenadaran. 